\title{
Influence of Streptomyces levoris CNMN-Ac-01 on meat productivity and chemical parameters of rabbit meat
}

\author{
M. A. Karaman \\ m_caraman@mail.ru \\ Scientific and Practical Institute of Biotechnologies in Zootechny and Veterinary Medicine, \\ Maximovca, Anenii Noi district, MD 6525, Republic of Moldova
}

The purpose of the work was to evaluate the influence of biomass of Streptomyces levoris $\mathrm{CNMN-Ac-01}$ added to fodder on meat productivity and chemical composition of rabbit meat. The experimental and control groups of animals (each one consisting of 5 rabbits) were formed according to analogous principles of age, sex (only females), body weight, mode of maintenance and feeding. The age of rabbits used for the experiment was 45 days. The control rabbits were fed with granulated fodder produced according to the recipe developed in the laboratory of Nutrition and Forage Technologies. The rabbits in experimental group were fed with the same granulated fodder supplemented with $0.1 \%$ biomass of Streptomyces levoris CNMN-Ac-01. The results of the chemical analyzes of the used fodder indicated that the elaborated fodder composition provide rabbits with all necessaries for their vital activity, where as added biomass of Streptomyces levoris $\mathrm{CNMN}-\mathrm{Ac}-01$ do not significantly affect its chemical composition. The increase of the protein content by $0.20 \%$ and water by $1.15 \%$ were observed in meat of experimental rabbits where the content of fat was decreased for $0.71 \%$ in comparison to those of the experimental group. The supplementing of streptomycete biomass in granulated fodder had an essential effect on the weight gain of rabbits and improves the bone and meat ratio in the carcass.

Key words: meat, chemical composition, rabbits, fodder, biomass, Streptomyces levoris CNMN-Ac-01

According to chemical composition, rabbit meat is superior to beef, sheep and other domestic animals, except for turkey meat, because it contains little fat and relatively more protein [8]. Another advantage of rabbit meat is the high content of minerals, especially potassium, phosphorus, magnesium and in addition high contents of $B$-complex vitamins, fat-soluble $A$ and $E$ vitamins and very low urate content $[4,7,9,10,13,17]$.

Due to the high degree of digestibility, rabbit meat is recommended by nutritionists as a valuable food for growing children, elderly people, patients with cardiovascular and metabolic diseases (diabetes, gout, obesity) and gastrointestinal disorders that have an increased incidence being considered diseases of contemporary civilization $[7-10,16]$.

Thus, rabbit meat corresponds to the nutritional requirements of consumers, due to the positive influence in maintaining the human health $[15,17]$.

It is important to mention that the chemical composition of rabbit meat is different even within the same species, varying from one individual to another depending on the ratio between different tissues, age, sex of the animal, fattening status, etc. [10,17].

Streptomyces are widespread in nature: in the air, waters, on plant and animal remains, but especially a lot of them are found in soil. In recent years, they are considered not only as producers of antibiotics of different chemical nature, but also of other bioactive substances as enzymes, vitamins, amino acids, lipids, vaccines against human and animal infectious diseases, various drugs of controlling insects and rodents, substances with a phytohormonal activity, which influence the growth and development of plants, stimulate seed germination, and increase crop yields [6, 11, 14]. More than a hundred of medicine drugs produced by soil actinomycetes are used in modern medicine [6].

The object of the study was a strain of Streptomyces levoris CNMN-Ac-01, isolated from soils of the R. Moldova and included in the National Collection of Non-Pathogenic Microorganisms of the Institute of Microbiology and Biotechnology of the Academy of Sciences of R. Moldova [2]. 
The purpose of this studying was to evaluate changes of chemical indices of rabbit meat in responce to the suplementation of granulated combined fodder with biomass of S. levoris CNMN-Ac-01.

\section{Materials and Methods}

The research was carried out on two lots of rabbits of three-breed crossbreeds $q$ ( $q$ Chinchilla $\times \hat{~ N e w}$ Zealand White) $\times \widehat{C}$ California (control lot and experimental lot) of 5 rabbits in each lot. The lots of rabbits were formed according to analogous principles of age, sex, body weight, mode of maintenance and feeding. The age of the rabbits included in the experiment was of 45 days.

The rabbits from the control lot were fed with granulated fodder produced at experimental technological station "Maximovca" according to the recipe elaborated in the Nutrition and Feed Technologies laboratory within Scientific and Practical Institute of Biotechnologies in Zootechny and Veterinary Medicine. The composition of the granulated compound fodder included: alfalfa hay flour, corn, wheat, barley, sunflower cake, soybean meal, alcohol borhot, grape pomace, limestone, vitamin and mineral premix $2 \%$ "Rabbit", and kitchen salt.

The rabbits in the experimental lot received the same granulated fodder with the addition of $0.1 \%$ biomass of

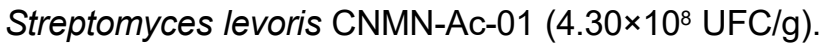
The duration of the experience was 60 days. After 60 days at the end of the experiment, rabbits of the experimental group were fed without Streptomyces during 18 days before slaughter. On the day of the slaughter, the age of the rabbits became 123 days.

At the end of the experiment, control slaughter of rabbits of both groups was carried out according to the corresponding method [1].

To study the chemical composition of the meat, the rabbit carcasses were cut into cuts and deboned. After deboning, minced meat was prepared and an average sample was taken. The chemical composition of the meat was examined at the Eagle lab's apparatus. It was determined the percentage ratio of water, fat, protein and collagen in the carcasses of rabbits in the control and experimental lots.

Statistical processing of the results of the experiment, in order to assess the significance of the differences consisted in grouping the material, calculating the arithmetic mean $(M)$, error $(m)$ and the confidence criterion [12].

\section{Results and Discussions}

Initially, the chemical composition of granulated compound feed with and without the supplementing of S. levoris CNMN-Ac-01 was studied. It was found that control and experimental granulated feed contain $18.18 \%$ and, respectively $18.23 \%$ of crude protein. The crude fat content in the dry matter constituted $2.83 \%$ in the experimental granulated fodder and $3.12 \%$ in the control one. Crude cellulose in the control granulated fodder constituted $16.30 \%$, and in the experimental granulated fodder $15.87 \%$ [5].

As a result of the study of the chemical composition of the control and experimental combined granulated forages, it was found that the biomass of $S$. levoris CNMN-Ac-01 did not significantly influence their chemical composition, and the developed granulated forage recipe provided rabbits with nutrients (crude protein, crude fat, etc.) necessary for their vital activity [5].

Until slaughter, the clinical examination of each rabbit was carried out and their body mass was determined.

As a result of the clinical examination of rabbits of control and experimental lots, were not found deviations from the physiological norm, and their general condition was good, the fur smooth and clean, the mucous membranes pale pink, without elimination or inflammatory processes.

After slaughter, were examined the carcasses and internal organs of the rabbits. The carcasses had a characteristic pink-red color (fig. 1, 2), white-yellow adipose tissue, internal organs without structural changes.

The average body mass at the age of slaughter is economically important, and some authors $[1,16]$ mention that it must constitute $50-60 \%$ of the weight of the adult rabbit. The better the adult rabbit is maintained before the time of slaughter, the higher is the slaughter yield and the better is the quality of the meat. Rabbits in the control lot, at the age of 123 days weighed $2790.80 \mathrm{~g}$, and those in the experimental lot by $4.53 \%$ more.

One of the most important characteristics of the productive qualities that determine the effectiveness of rabbit breeding is slaughter indicators. Rabbits at earlier terms reach certain indicators of live weight and slaughter qualities $[9,10]$. The meat qualities of rabbits were assessed by the pre-slaughter and slaughter weights, and the slaughter yield was calculated based on the weighing results. Table 1 shows the analysis of indicators of slaughter of rabbits.

Table 1. Results of control slaughter of rabbits $(M \pm m, n=5)$

\begin{tabular}{|c|c|c|}
\hline Indicators & Control lot & Experimental lot \\
\hline \multicolumn{3}{|c|}{ Slaughter qualities } \\
\hline Pre-slaughter live weight, g & $2790.80 \pm 49.71$ & $2917.20 \pm 30.82$ \\
\hline $\begin{array}{l}\text { Freshly slaughtered } \\
\text { carcass weight, g }\end{array}$ & $1358.00 \pm 33.06$ & $\begin{array}{c}1478.40 \pm 30.84^{*} \\
(\mathrm{td}=2,66)\end{array}$ \\
\hline $\begin{array}{l}\text { Chilled carcass weight, kg } \\
\text { (after } 24 \text { hrs) }\end{array}$ & $1347.20 \pm 32.38$ & $\begin{array}{c}1467.60 \pm 30.73^{*} \\
(\mathrm{td}=2,70)\end{array}$ \\
\hline $\begin{array}{l}\text { Kidney weight } \\
\text { with perineal fat, } g\end{array}$ & $90.00 \pm 9.78$ & $113.60 \pm 10.80$ \\
\hline Slaughter weight, g & 1437.20 & 1581.20 \\
\hline Slaughter output/yield, \% & 51.50 & 54.20 \\
\hline \multicolumn{3}{|c|}{ Morphological composition of carcasses } \\
\hline Half carcass weight, $\mathrm{g}$ & $729.33 \pm 5.70$ & $740.33 \pm 22.30$ \\
\hline meat & $526.00 \pm 9.45$ & $571.33 \pm 6.77$ \\
\hline bones & $202.00 \pm 11.14$ & $166.67 \pm 13.87$ \\
\hline meat coefficient & 2.60 & 3.43 \\
\hline
\end{tabular}

Note. * $-\mathrm{P} \leq 0.05$. 


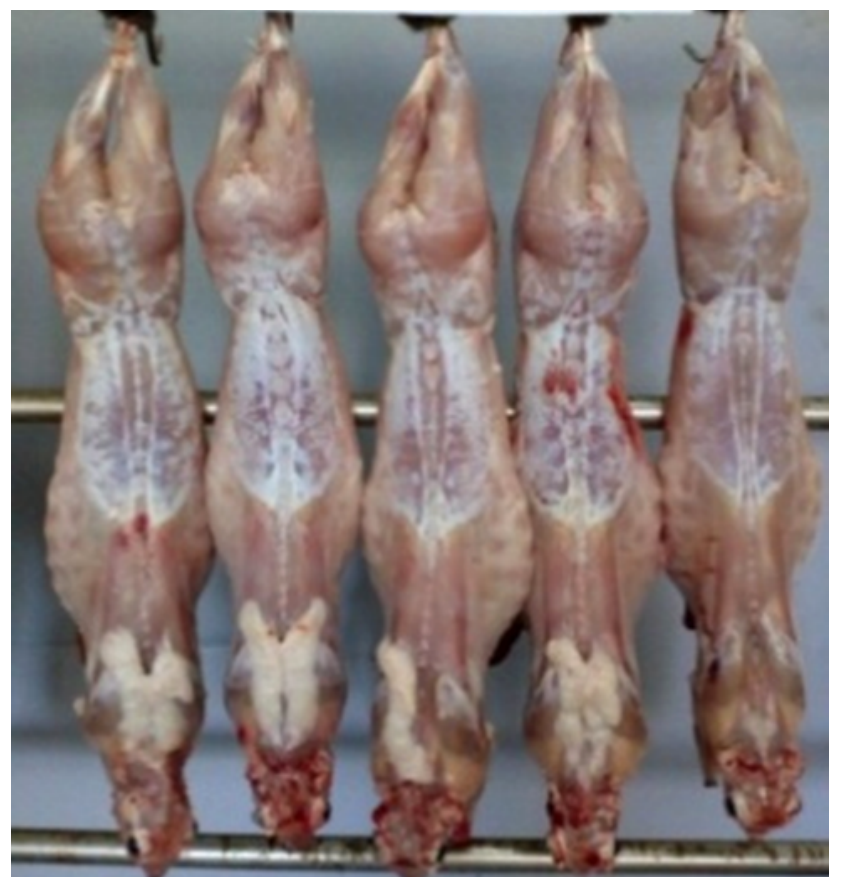

Fig. 1. Rabbit experimental carcasses

The weight of freshly slaughtered carcass in the rabbits of the experimental group is by $120.4 \mathrm{~g}$ higher in relation to the control group, the difference is significant ( $\mathrm{td}=2.66$ ), as well as in the weight of the chilled carcass. The slaughter yield is the ratio of slaughter weight to live weight before slaughter expressed in percentages. It is recommended that this ratio must be increased as much as possible. Its value differs depending on the state of maintenance of the rabbit, breed and age. In the control lot the slaughter yield was $51.50 \%$, and in the experimental one it achieved $54.20 \%$ or by $2.7 \%$ higher.

As a result of the carried out research, it was found that, in the meat of rabbits from the experimental lot, the water was $75.22 \%$, or lower by $1.15 \%$ in comparison to control lot (table 2).

The proteins are found in the muscle tissues that is the most important component of meat. In relation to the meat of other domestic animals, the rabbit meat is characterized by the highest percentage of protein, being of great nutritional value.

In the meat of rabbits, in the experimental lot was $19.19 \%$ protein and $1.31 \%$ collagen, being respectively by $0.2 \%$ and $0.1 \%$ more compared to the control lot.

Table 2. Chemical composition of rabbit meat, \%

\begin{tabular}{l|c|c|c|c|c|c}
\multirow{2}{*}{ Specify } & \multicolumn{3}{|c}{ Control lot } & \multicolumn{3}{c}{ Experimental lot } \\
\cline { 2 - 8 } & $\mathrm{M} \pm \mathrm{m}$ & $\delta$ & $\mathrm{Cv}, \%$ & $\mathrm{M} \pm \mathrm{m}$ & $\delta$ & $\mathrm{Cv}, \%$ \\
\hline Water & $74.07 \pm 0.34$ & 0.59 & 0.79 & $75.22 \pm 0.88$ & 1.53 & 2.04 \\
Fat & $5.47 \pm 0.41$ & 0.71 & 12.95 & $4.76 \pm 0.58$ & 1.01 & 21.25 \\
\hline Protein & $18.99 \pm 0.08$ & 0.13 & 0.68 & $19.19 \pm 0.21$ & 0.36 & 1.86 \\
\hline Collagen & $1.30 \pm 0.03$ & 0.06 & 4.28 & $1.31 \pm 0.05$ & 0.09 & 7.11 \\
\hline
\end{tabular}

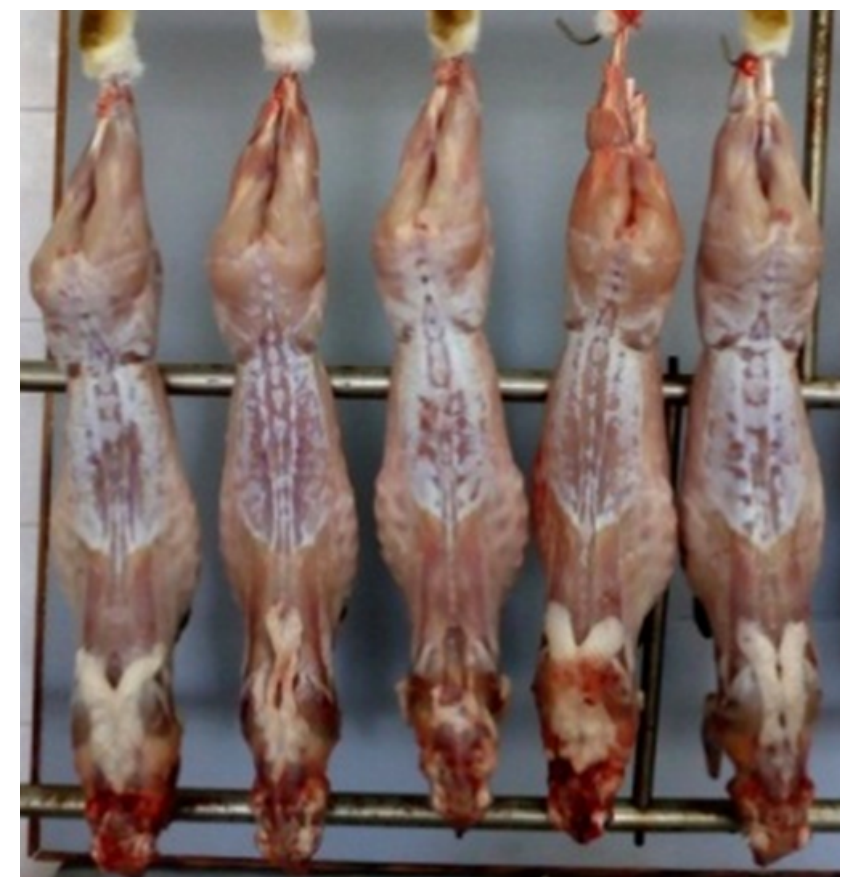

Fig. 2. Rabbit control carcasses

According to some authors $[1,10,16]$, the excessive fat content reduces the nutritional quality of rabbit meat by decreasing the percentage of protein, so they must be slaughtered until the age of 110-120 days. The rabbit fat is a bioactive substance and a good natural immunomodulator. It is well absorbed by human body and is better in quality than the fats of some other animals. In the meat of rabbits of the control lot, the amount of fat was $0.71 \%$ higher compared to the experimental lot.

The ratio of water : protein and water : fat in the meat of the rabbits of the control lot was 3.90:1 and $13.54: 1$, respectively, and of the experimental one $3.92: 1$ and $15.80: 1$.

\section{Conclusions}

The rational use of granulated fodder with the addition of Streptomyces levoris CNMN-Ac-01 biomass contributed to obtaining meat with an optimal content of water, protein and fat. At the end of the research period, the body mass of rabbits of the experimental lot exceeded that of rabbits of the control lot by $4.53 \%$, and the ratio of bones and meat in the carcass was $1: 3.43$ in favor of the experimental lot, which is 0.83 higher in comparison to the control group.

The chemical composition of rabbit meat in experimental group is of the best quality, juicy, with a high protein content $(19,19 \pm 0.21 \%)$ and with a low amount of fat $(4.76 \pm 0.60 \%)$. The increase of the content of protein by $0.20 \%$ and water by $1.15 \%$ were observed in meat of experimental rabbits where the content of fat was decreased by $0.71 \%$ if compared to those of the experimental group. 


\section{Prospects for Further Research}

In further studies it will be developed a pilot batch of a biological product containing biomass and fluid culture of the Streptomyces levoris CNMN-Ac-01 strain. It is planned to conduct pilot production tests of different concentrations of biomass from $0.1 \%$ to $1.0 \%$ (in the composition of granular feed) and fluid culture from $0.5 \%$ to $2.0 \%$ (with its addition into the water) on rabbits. For the reliability of the results, the experiment will be conducted on a large number of animals.

1. Bura M. Creşterea iepurilor de casă în România. Sistemul propriu. Ferma. 2005; 1: 59 p. (in Romanian)

2. Burţeva S, Bîrsa M, Achiri I, Chiseliţă O. The effect on cultural, antimicrobial and growth-regulatory properties of Streptomyces levoris CNMN-Ac-01 by using difference methods of storage. $2^{\text {nd }}$ International Conference on Microbial Biotechnology, Chisinau, Moldova, 2014: 108 p. (in Moldovan)

3. Compoziţia chimică a cărnii. Meat Milk. 2013. Available at: http:// www.meat-milk.ro/compozitia-chimica-a-carnii (in Romanian)

4. Gidenne T, Carabaño R, Badiola I, Garcia J, Licois D. L'écosystème caecal chez le lapin domestique: Impact de la nutrition et de quelques facteurs alimentaires Conséquences sur la santé digestive du lapereau. 12 J. Recher. Cunicole. 2007: 59-72. Available at: http:// www.journees-de-la-recherche.org/PDF/Sa-gidenne.pdf (in French)

5. Caraman M, Moscalic R, Coșman V, Burţeva S, Bîrsa M. Impact of biomass of Streptomyces levoris CNMN-Ac-01 and some external factors on quality of combined fodder for rabbits. Sci. Papers, Ser. Managem., Econ. Engin. Agricult. Rural Devel. 2019; 19 (1): 97-101. Available at: http://managementjournal.usamv.ro/ index.php/scientific-papers/1827-impact-of-biomass-ofstreptomyces-levoris-cnmn-ac-01-and-some-external-factorson-quality-of-combined-fodder-for-rabbits (in Romanian)

6. Chiseliţă O, Burţeva S, Bîrsa M, Bulimaga V, Vasilciuc, A. Viability and antimicrobial activity of streptomyces strains from NCNM after Iyophilization. Studia Univer. Moldaviae, Ser. Științe Reale și ale Naturii, 2016; 1 (91): 61-71. Available at: http://ojs.studiamsu.eu/ index.php/real-nature/article/view/406 (in Moldovan)
7. Liutskanov PI, Mashner OA, Evtodienko SA. The morph-productive qualities of metis rabbits resulting from crossing of different breeds. Effect. Rabbit Breed. Anim. Husbandry. Cherkasy, 2019; 5: 7-16. DOI: 10.37617/2708-0617.2019.5.7-16. (in Ukrainian)

8. Macovschi B. Un aliment dietetic carnea de iepure. Lumea Satului. 2014. Available at: https://www.lumeasatului.ro/articole-revista/ 1452-un-aliment-dietetic-carnea-de-iepure.html (in Romanian)

9. Mardari T. Caracteristicile tehnologice a cărnii iepurelui de casă. IBN, 2010: 209 p. Available at: https://ibn.idsi.md/sites/default/files/ imag_file/209-212_5.pdf (in Moldovan)

10. Mardari T. Variaţia compoziţiei chimice a cărnii de iepure de casă în funcţie de vârstă, Știința Agricolă. 2015; 2: 88-92. Available at: http://dspace.uasm.md/bitstream/handle/123456789/4289/mardari 88-92.pdf?sequence=1\&isAllowed=y (in Moldovan)

11. Palmer T, Hutchings MI. Protein secretion in streptomyces. In: Streptomyces: Molecular Biology and Biotechnology. Ed. by P. Dyson. Caister Academic Press, 2011: 87-104. Available at: https://www.caister.com/hsp/abstracts/streptomyces/04.html

12. Plokhinskiy NI. Biometrics Guide for Animal Technicians. Moscow. 1969: 256 p. (in Russian)

13. Priguza C, Stamati V, Timmer D, Sekula M. Totul despre creșterea iepurilor de casă: sfaturi utile pentru o afacere profitabilă. Agrobiznes. 2015. Available at: https://agrobiznes.md/totul-desprecresterea-iepurilor-de-casa-sfaturi-utile-pentru-o-afacereprofitabila.html (in Moldovan)

14. Rudic V, Popova N, Crivova A, Boortseva S, Rastimeshina I. Biosynthesis of lipoxygenase, lipids and fatty acid composition of Actinomycetes and Yeast. Roum. Biotechnol. Lett. 2002; 7 (3): 711-716. Available at: https://e-repository.org/rbl/vol.7/ iss.3/3.pdf (in Romanian)

15. Sautkin A. Veterinary and sanitary assessment of rabbit meat when using the drug "Amisel" in their diet. Diss. Doc. Sci., Moscow, 2010: 137 p. (in Russian)

16. Șumanschii A, Macari A, Dabija T, Liuțcanov P, Paniș G. Tehnologii semi intensive și intensive de creștere și exploatare a iepurilor de casă. Print-Caro. 2011: 56 p. (in Moldovan)

17. Tarnauceanu G. Rezumatul tezei "Cercetări privind caracterizarea statusului morfofiziologic la iepurele de casă şi de câmp în corelaţie cu proprietăţile senzoriale şi nutritiv-biologice ale cărnii”. 2013. Available at: http://www.uaiasi.ro/ro/files/doctorat/2013/2013_feb_ Tarnauceanu_Gabriela_ro.pdf (in Romanian)

\title{
Вплив Streptomyces levoris CNMN-Ac-01 на м'ясну продуктивність і хімічні показники м'яса кроликів
}

\author{
М. А. Караман \\ m_caraman@mail.ru
}

Науково-практичний інститут біотехнології в зоотехнії і ветеринарній медицині Республіки Молдова, с. Максимівка, Новоаненський р-н, МД 6525, Республіка Молдова

Метою роботи було оцінити вплив біомаси Streptomyces levoris CNMN-Ac-01, доданої до корму, на м'ясну продуктивність і хімічний склад м'яса кролів. Експериментальні та контрольні групи тварин (кожна по 5 кроликів) були сформовані за принципами аналогів: за віком, статтю (тільки самки), масою тіла, режимом утримання та годування. Вік кроликів, використаних в експерименті, становив 45 днів. Контрольні кролики отримували гранульований корм, вироблений за рецептурою, розробленою в лабораторії кормів і технології годівлі. Кролики дослідної групи отримували однаковий гранульований корм з додаванням $0,1 \%$ біомаси Streptomyces levoris CNMN-Ac-01. Результати хімічного аналізу застосованого корму показали, що розроблений кормовий склад забезпечує кроликів всім необхідним для життєдіяльності, тоді як додана біомаса Streptomyces levoris CNMN-Ac-01 істотно не впливає на його хімічний склад. У м'ясі дослідних кроликів спостерігали збільшення вмісту білка на 0,20\% і води на $1,15 \%$, тоді як вміст жиру знизився на 0,71\% порівняно з цим показником у контрольній групі. Додавання біомаси стрептоміцетів до гранульованого корму значно вплинуло на приріст кроликів і поліпшило співвідношення кістки до м'яса : м'ясо в туші.

Ключові слова: м'ясо, хімічний склад, кролики, корм, біомаса, Streptomyces levoris CNMN-Ac-01

Karaman MA. Influence of Streptomyces levoris CNMN-Ac-01 on meat productivity and chemical parameters of rabbit meat. Biol. Tvarin. 2021; 23 (1): 34-37. DOI: 10.15407/animbiol23.01.034. 